\title{
TRAUMATIC SHOCK: IV. A STUDY OF THE PROBLEM OF THE "LOST PLASMA" IN HEMORRHAGIC SHOCK BY THE USE OF RADIOACTIVE PLASMA PROTEIN
}

\author{
By JACOB FINE AND ARNOLD M. SELIGMAN \\ (From the Surgical Research Department of the Beth Israel Hospital and the Department of \\ Surgery, Harvard Medical School, Boston)
}

(Received for publication October 29, 1942)

A prevailing opinion is that an increased permeability of the capillaries exists in shock and that a consequent loss of plasma into tissues ensues, so that the effective circulating blood volume falls to a level incompatible with life. This loss of plasma is presumed to occur generally throughout the body as well as in areas of local injury, because the replacement of all or more than can be accounted for as lost at the site of injury is unable to sustain the organism. The evidence in favor of this theory is derived from the following: (1) There is peripheral stagnation of circulating blood, as shown by hemoconcentration, cyanosis, lowered venous oxygen, decreased venous return to the heart, decreased $\mathrm{pH}$ of venous blood, and prolonged circulating time; (2) the tissues are wet or hemorrhagic; and (3) the circulating plasma volume, as determined principally by dye methods, is reduced sharply.

The difficulty in accepting this evidence as conclusive is that fatal shock may occur in the absence of some of the above-mentioned features. For example, hemorrhagic or edematous tissues and hemoconcentration are not usually found in fatal shock resulting from simple hemorrhage. When they do occur, they may be explained as phenomena of tissue deterioration in a dying organism, whatever the cause, more especially if an abundance of intravenous fluids has been supplied. The decline in effective circulating volume and in the volume of venous return to the heart are constant findings, but they are readily accounted for by the loss of blood in the case of shock from hemorrhage, or the escape of plasma into areas of injury in such types of shock as trauma, burns, infections, and intestinal strangulation. The fact, however, that adequate replacement of a known or calculated plasma loss will reverse the deteriorating trend in shock if given sufficiently early, but not if given late, has led to the inference that the plasma escapes everywhere from the circulation in the late or irreversible phase because of capillary "leakage." It is, moreover, clear that a fatal loss of plasma ( 40 per cent), if generally and evenly distributed throughout the body, may not be detectable by ordinary methods of measurement. Hence, the elusive nature of the "lost plasma." Obviously, it is essential to establish or deny the claims for the "lost plasma" hypothesis if we are to be properly oriented, not only as to the mechanisms involved, but as to the direction by which improvement in therapeutic techniques may be achieved.

Since the incorporation of a radioactive element into the plasma protein molecule provides an unmistakable label for the identification of plasma proteins, which presumably would be lost with the non-protein fraction, the use of such radioprotein was considered a more promising technique for the solution of the "lost plasma" problem than other available methods.

Such labelled proteins are valid tools so long as they are not denatured in preparation or do not behave like a foreign protein when used in the experimental animal. Accordingly, sulfur, a natural constituent of plasma protein, was first selected as the element to be made radioactive for incorporation into the protein. The special problems involved in this synthesis have been fully discussed in preceding papers of this series $(1,2)$. The prepared radioactive sulfur-containing plasma protein has been sufficient for study of its disappearance rate upon injection intravenously into the normal and shocked dog, but extensive observations could only be made with extraordinary difficulty because, (1) radioactive sulfur can be obtained only occasionally and in small amounts, (2) the synthesis of radiosulfurcontaining 1-cystine can be achieved at best with only an 8 per cent yield on the basis of sulfur, 
and (3) the yield of plasma protein is only 15 per cent on the basis of radioactive 1-cystine fed. For this reason, radiobromoprotein, which can be prepared relatively easily (as will be described below) was utilized for the bulk of the observations. This was possible because it was found that radiobromoprotein, containing less than 0.1 per cent bromine, possessed nearly as slow a disappearance rate from the blood stream of normal dogs as radiosulphprotein.

This communication is concerned with a study of the movement of plasma and plasma protein from the blood stream into the tissues in the normal dog and in the dog shocked by hemorrhage. The data at hand contradict the theory that a progressively increasing loss of plasma from the circulation occurs in shock due to hemorrhage.

\section{METHOD}

\section{Preparation of plasma protein containing radioactive sulfur}

The preparation of radioactive plasma protein from radioactive sulfur-containing cystine by hypoproteinemic dogs, was described in a preceding paper (2). Radioactive plasma was removed from these dogs and dialysed for 36 hours in running tap water. In order to prevent the extensive precipitation of globulins which are redissolved with difficulty, $1.0 \mathrm{cc}$. of 25 per cent sodium carbonate per $10 \mathrm{cc}$. plasma was added before dialysis was begun. Dialysis was continued in physiological saline as soon as precipitation occurred. When desired, plasma was concentrated by evaporation in a cellophane bag with electric fan ventilation. Following dialysis, radioactivity of the non-protein fraction of plasma represented 0.14 per cent of the total radioactivity. The preparation of tissue and plasma containing radioactive sulfur for radioactivity measurement is described in paper I of this series (2).

\section{Preparation of radioactive bromoprotein}

Radioactive bromine was obtained from ethyl bromide after neutron bombardment, by two extractions with 400 cc. each of 2 to 3 per cent sodium carbonate. Two per cent sodium sulfate was added to prevent emulsification. The aqueous extract was then extracted with ether to remove ethyl bromide. 1 A few pellets of sodium hydroxide were added to the aqueous extract (some 800 cc.), which was then evaporated to 100 cc., cooled and

1 Unless this procedure is followed, or if stronger alkali is used, excessive hydrolysis of ethyl bromide1.0 to $1.5 \mathrm{grams}$ bromine from $35 \mathrm{kgm}$. ethyl bromideresults. Wet ethyl bromide was stored in the cold. By the procedure outlined, as little as 20 to $\mathbf{4 0} \mathrm{mgm}$. bromine are obtained from $35 \mathrm{kgm}$. of ethyl bromide. neutralized with cold 50 per cent sulfuric acid. The solution was then transferred to an all-glass distilling apparatus with water cooled condenser, ice-cooled water trap, and final trap containing a small amount of 25 per cent sodium carbonate solution. A mixture of powdered manganese dioxide in concentrated sulfuric acid was added in excess, and the mixture was heated to boiling. An estimate of the quantity of bromine obtained was made from the volume of bromine and bromine water.

The cold bromine and bromine water were added at once with swirling to 10 . to $15 \mathrm{cc}$. of a cold 25 per cent sodium carbonate solution. The resulting yellow solution of sodium hypobromite was added immediately to 30 to $60 \mathrm{cc}$. of cold plasma. After thorough mixing, it was allowed to stand at room temperature for 45 minutes. An aliquot of this solution was taken for determination of the radioactivity of the total bromine used in bromination of the plasma. The remaining solution was placed in cellophane tubing ( $11 / 8$ inches in diameter) which was ligated with 3 ties, close to the top of the column of solution, to prevent too large uptake of water. It was then dialysed in running tap water for 36 hours. The bag was slowly rotated during this time. Only a slight amount of precipitate formed during the dialysis. This was centrifuged and the supernatant fluid used in the experiments to be described.

An aliquot was taken for determination of the amount of radioactive bromine attached to protein. The activity of the non-protein fraction was determined with the filtrate obtained after precipitation with an equal volume of 20 per cent trichloroacetic acid. Values varying from 0.2 to 0.8 per cent of the total activity of the plasma were found in this non-protein fraction. With these data, it was possible to calculate the percentage of the bromine used in the bromination which was attached to the plasma protein. This varied from 20 to 30 per cent.

From the approximate weight of bromine used in bromination, the percentage utilization, and the plasma protein concentration, the percentage bromine in the bromoprotein was calculated. This varied from 0.05 to 5.0 per cent. From the estimated minimal molecular weights (3) of serum albumin $(45,000)$ and serum globulin $(81,000)$, it is evident that if one atom of bromine (82) is incorporated in each protein molecule, the resulting percentage of bromine in bromoalbumin would be 0.18 per cent and in bromoglobulin 0.10 per cent. Therefore, in order to tag a maximum number of protein molecules with a minimum number of radioactive bromine atoms, the optimal percentage of bromine in the bromoprotein desired should be 0.1 to 0.2 per cent. Bromoprotein containing 5 per cent bromine would contain 35 bromine atoms on each protein molecule.

When the bromination was conducted in stronger alkali, a more denatured soluble protein was obtained. Equally efficient bromination of protein was obtained with sodium hydroxide as with sodium carbonate, but evidence of denaturation of the protein appeared from the fact that protein disappeared from the circulating plasma in normal animals at an abnormal rate. Ammonium hydroxide was 
unsatisfactory because it rapidly decomposed the sodium hypobromite.

\section{Stability of the bromine linkage in radioactive bromo- protein}

In order to determine the ease with which bromine could be removed from its points of attachment in the protein molecule, a specimen of radioactive dialysed plasma was hydrolysed with trypsin and sulfuric acid.

Trypsin hydrolysis. To $2.0 \mathrm{cc}$. of plasma were added $15 \mathrm{mgm}$. of crystalline trypsin and the mixture was incubated at $37^{\circ} \mathrm{C}$. for 3 hours. A very slight precipitate was obtained when an equal volume of 20 per cent trichloroacetic acid was added.

Sulfuric acid hydrolysis. Plasma $(2.0 \mathrm{cc}$.) and $6.0 \mathrm{cc}$. of 25 per cent sulfuric acid were heated in a sealed tube at $70^{\circ} \mathrm{C}$. for 7 hours. A slight precipitate was obtained when an equal volume of 20 per cent trichloroacetic acid was added.

To each filtrate obtained as described above, and to the non-protein filtrate prepared in the same way from 2.0 cc. of plasma, potassium bromide equivalent to 7.0 $\mathrm{mgm}$. of silver bromide was added, followed by an excess of silver nitrate. The precipitates were collected and the radioactivity of each was determined.

The plasma was found to contain 0.85 per cent of its radioactivity as ionic bromide. After trypsin hydrolysis, this increased to 2.6 per cent and after sulfuric acid hydrolysis, it increased to 3.0 per cent. Analysis of the urine of a dog which was given $30 \mathrm{cc}$. of this specimen of dialysed radioactive plasma intravenously, showed an excretion (as ionic bromide) of 1.3 per cent of the radioactivity which was injected, in a 12 -hour period.

In another experiment, $100 \mathrm{cc}$. of radioactive dialysed plasma, containing 0.5 per cent of its radioactivity as ionic bromide, was given intravenously to a dog. Analysis of pooled plasma specimens, collected over a period of 12 hours, showed a content of 3.7 per cent of the radioactivity in the ionic bromide fraction.

In still another experiment, pooled plasma from 3 dogs (normal and shocked), one half hour after injection of radioactive bromoprotein, showed 0.07 per cent of the radioactivity in the non-protein fraction and $\mathbf{5}$ hours later the non-protein fraction contained 1.1 per cent of the plasma radioactivity.

This experimental evidence indicated that some 3.0 per cent of the radioactive bromine incorporated in the plasma protein could be liberated by in vitro or in vivo hydrolysis, but that some 97 per cent was firmly found in one or more amino acids, presumably tyrosine and possibly tryptophane (4). It is expected that bromine in such a linkage would be liberated by nothing less than destruction or degradation of the aromatic ring holding the bromine atom.

\section{Preparation of plasma and tissues containing radioactive bromine for radiactivity analysis}

Because bromine emits a $\beta$-ray of sufficient penetrability $(0.7 \mathrm{Mev}$.$) , it is possible to prepare plasma, lymph, or$ urine for radioactivity measurements simply by evapora- tion to dryness. For accurate comparison of specimens, the dry weight of the specimens should be approximately the same.

For analysis of tissue for content of radioactive bromine, it was found desirable to oxidize the specimen in the presence of silver nitrate and measure the radioactivity of the resulting silver halides. The weight of silver halides was kept constant as far as possible (see below). For accurate comparison of plasma and tissue radioactivity, the silver salt method was used for both.

Each specimen for analysis (1 gram) was oxidized in a $100 \mathrm{cc}$. Kjeldahl flask with nitric acid and superoxol in the presence of an excess of silver nitrate (equivalent to $30 \mathrm{mgm}$. silver bromide). A standard weight of potassium bromide (equivalent to $7.0 \mathrm{mgm}$ of silver bromide) was added to each flask. When standard dilutions of plasma were oxidized, chloride content was made up by adding $1.0 \mathrm{cc}$. of normal plasma or $0.5 \mathrm{cc}$. of 0.9 per cent saline solution.

The oxidation required 1.5 to 2.0 hours. Care was taken to avoid ignition when approaching dryness. Nitric acid and superoxol were added in small quantity alternately until an ash was formed. Heating was continued until nitric fumes disappeared. Fumes were removed by water pump aspiration through a tube which fitted loosely over the top of the Kjeldahl flask. The resultant yellowish-white ash was dissolved in 15 to 20 cc. of concentrated ammonium hydroxide. This was facilitated by leaving the ash in the ammonia overnight. A small amount of white ash (usually noted with tissue such as liver and kidney) failed to dissolve. This was ignored, since it was found to be acid soluble (probably phosphate). The solution was then transferred to a $50 \mathrm{cc}$. beaker, with the aid of additional ammonia. The solution was evaporated smoothly on a hot plate until a precipitate began to form. Two to $3 \mathrm{cc}$. of 20 per cent nitric acid were than added and the evaporation continued to 3 to 4 cc. An additional 2 to 3 cc. of 20 per cent nitric acid was added and the mixture was allowed to remain in the dark and cold for one half hour. The precipitate was then collected over an area of $1.54 \mathrm{sq} . \mathrm{cm}$. in a filtration apparatus already described (2). The precipitate was washed with water, acetone, and finally, an acetone solution of vinylite, and sucked dry. Care was taken to secure a layer of uniform thickness. It was found that the vinylite film agglutinated the silver salt particles into a flexible, easily handled layer. Precipitates weighing 14 to $16 \mathrm{mgm}$. were regularly obtained.

To test the reliability of this method of oxidation and precipitation, standard dilutions of radioactive bromoprotein were made with normal plasma. Comparative measurements of radioactivity were made with both evaporated and oxidized specimens (Table III of foregoing paper). Greater deviation from linearity was noted in oxidized specimens (consistent loss).

\section{Measurement of radioactivity}

Radioactivity measurements were made with a modified Lauritsen electroscope described in the preceding paper 
(5). Plasma (1.0 cc.) was evaporated in an electric oven at $85^{\circ}$ to $90^{\circ} \mathrm{C}$. in shallow brass cups of uniform size, which were introduced in a fixed position into the electroscope chamber by means of a sliding bar device. Precipitates of silver bromide on filter paper were also introduced in brass cups in the same manner. Parallel "evaporated" and "oxidized" specimens of standards of radiobromoprotein solutions used for injection were read, so as to permit tissue calculations.

All standards and specimens were measured on the same day, the time of measurement of each was recorded, and the decay for the total period of electroscopic analysis determined by repeating the measurement of the first specimen. Radioactivity in division per second for each specimen was corrected to zero time. When such measurements were made, as was usually the case, 5 to 6 days after the preparation of the radioactive bromine, short half-life bromine had deteriorated to such an extent that the rate of decay corresponded fairly well with the rate of decay of 34-hour half-period bromine $\left(\mathrm{Br}^{28}\right)$.

Rate of disappearance of radioactive plasma protein from plasma of normal dogs

In the course of the experiments to be reported, radioactive plasma was given to normal anesthetized and unanesthetized dogs, intravenously. The rate of disappear- ance of radioactive protein from the circulating plasma was determined in each case. The percentage of the radioactive protein injected, which was found circulating in the plasma, was calculated from the unit radioactivity of plasma, the plasma volume, and the total radioactivity of the protein injected.

In the case of the plasma protein containing radioactive sulfur, 90 per cent of the radioactive protein was circulating 5 hours after injection, 70 per cent, 15 hours after injection, and 45 per cent, 48 hours after injection in two experiments.

The results with plasma protein containing radioactive bromine were more variable, depending upon the degree of denaturation of the protein. Denaturation was increased by increasing the bromine content of protein and by bromination in strong alkali. Figure 1 is a composite of these results with radioactive plasma protein in normal anesthetized dogs. The slowest rate of disappearance of radioactive bromoprotein comparable to the rate of disappearance of radioactive sulfur-containing protein was obtained with bromoprotein having less than 1 per cent bromine and prepared with sodium carbonate. Because of the variation in the rate of disappearance from the circulation of bromoprotein with different bromine percentages, and because of the impossibility of preparing radioactive bromoprotein of constant bromine composition, it

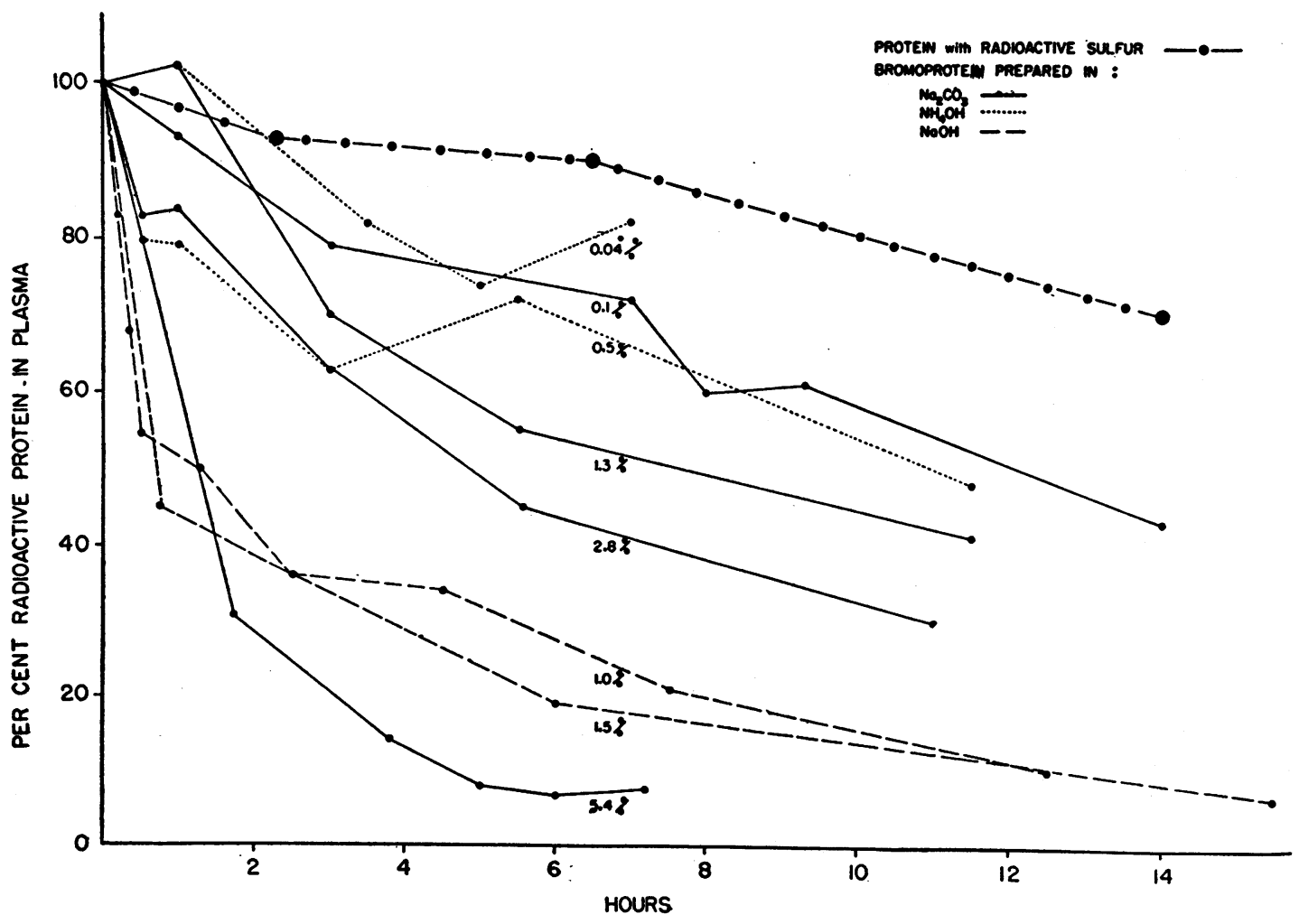

Fig. 1. Rate of Disappearance of Radioactive Bromoprotein (containing various percentages of bromine and prepared in several ways) from the Circulating Plasma of Normal Anesthetized Dogs, Compared to Radioactive Plasma Protein Containing Radioactive Sulfur 
was necessary to use a normal dog as a control in every shock experiment in which plasma containing radioactive bromoprotein was used for the study of the movement of plasma. No difference was noted between anesthetized and non-anesthetized dogs in the rate of disappearance of this bromoprotein from the plasma.

\section{A comparison of shocked and normal dogs in the rate of disappearance of radioactive plasma protein from the circulation and the distribution of radioactive protein in the tissues}

Procedure. Dogs were anesthetized (3 exceptions) with morphine sulfate (3 mgm. per $\mathrm{kgm}$.) and sodium barbital, according to Wiggers' technique (6). In three cases, morphine sulfate ( $2 \mathrm{mgm}$. per $\mathrm{kgm}$.) only was given and local anesthesia was used. Plasma volumes were determined by the method of Gibson and Evelyn (7). Plasma total protein was determined by the method of Kagan (8). In most cases, bleeding was accomplished as follows: A massive withdrawal of blood corresponding to 1 to 2 per cent of the body weight was made, followed by successive smaller withdrawals at 20 minute intervals, until a blood pressure of $70 \mathrm{~mm}$. $\mathrm{Hg}$ was reached. No further blood (except analytical samples) was removed. Blood pressures were taken by needle puncture of the femoral artery. All injections were made intravenously. All blood samples (heparinized) were taken from the femoral artery.

The amount of blood in each tissue, analysed for radioactive protein, was also determined by extraction of hemoglobin with water. A convenient method of doing this was to let the finely minced tissue stand in water for 48 hours in the icebox. After appropriate dilution, hemoglobin was determined by the benzidine method (9). Blood diluted 10,000 times was used as standard. On the basis of the hemoglobin content of each tissue and the arterial hematocrit at the conclusion of the experiment, the approximate intravascular plasma content of the tissue was calculated. Although it is recognized that the arterial differs from the capillary hematocrit, the error introduced, so far as intravascular plasma content of tissue is concerned, is small. Experiments are in progress, however, to determine the discrepancy between arterial and capillary hematocrit in normal and shocked dogs. On the basis of the unit radioactivity of the circulating plasma at the end of the experiment, the radioactivity of the intravascular plasma in 1.0 gram of tissue was calculated. This was used to calculate the extravascular radioactive protein in $1.0 \mathrm{gram}$ of tissue.

When the animals had been exsanguinated (the usual procedure in order to reduce blood content of tissues), the correction for blood content of tissue in skin, bowel, brain, and omentum was too small to be significant. The determination of the hemoglobin content of skeletal and heart muscle gave high values because of the presence of myoglobin. There are very few red cells in the physiological saline used for extraction of blood from carefully minced muscle, as compared to the number found in other tissues, such as lung, similarly treated.
The correction for blood in any case would only be necessary in muscle showing plasma loss. Since this occurred only twice in 12 instances (see Table II), no correction for blood in muscle need be applied. Corrections for blood in liver, kidney, and lung were necessary because of considerable variations in blood content.

Radioactive plasma was given intravenously to a normal and a shocked dog simultaneously, some time before or immediately after the shocked dog had been bled. The dose was the same in proportion to body weight in both dogs except in Experiments $8 \mathrm{~A}$ and $8 \mathrm{~B}$. The volume was usually too small to affect the total volume significantly. If the volume of plasma injected was over 25 cc., blood was withdrawn to balance that given. The disappearance curve of the radioactive protein was determined by sampling at intervals until the death of the shocked dog. In several instances, the latter received intravenous saline or plasma late in shock. In some experiments, only disappearance curves were studied and in others, tissues were taken for radioactivity measurements immediately after death following exsanguination. The disappearance curves (Figures 2 to 8 ) are shown in percentage of radioactive protein given, circulating in plasma as a function of time, as well as in terms of radioactivity per cc. of plasma as a function of time. The percentage of the radioactive protein injected which was circulating in plasma was determined from the measured or estimated plasma volume and the unit activity of plasma from the formula:

\section{Percentage radioactive protein in plasma $=\frac{\text { Plasma volume } \times \text { radioactivity per cc. } \text { plasma }}{\text { Radioactivity injected }} \times 100$}

The radioactive protein removed with the withdrawn blood was corrected for at any given time by the formula:

Percentage radioactive protein in plasma

$$
=\frac{\text { Plasma volume } X \text { radioactivity per cc. plasma }}{\text { Radioactivity injected-radioactivity removed }} \times 100
$$

When the radioactive protein was given to both dogs before the shocked one had been bled, the total circulating radioactive protein in the shocked dog after bleeding was of course reduced by the percentage of the total plasma withdrawn, but the concentration remained about the same in both animals, except for a slight decrease in unit activity caused presumably by dilution resulting from mobilization of extravascular fluids. When the radioprotein was given to both dogs after the shocked one had been bled, the total circulating protein given was the same in proportion to the body weight in both dogs. In that case, the smaller circulating volume of the shocked dog resulted in a greater unit activity. When the dose was given in proportion to volume of circulating plasma, the unit activity was the same in both. Since the tissue accumulation of radioactive protein is presumably proportional to the unit activity under ordinary conditions of capillary permeability, a comparison of the radioactivity content of the tissue of the normal and shocked dogs required correction in accordance with 


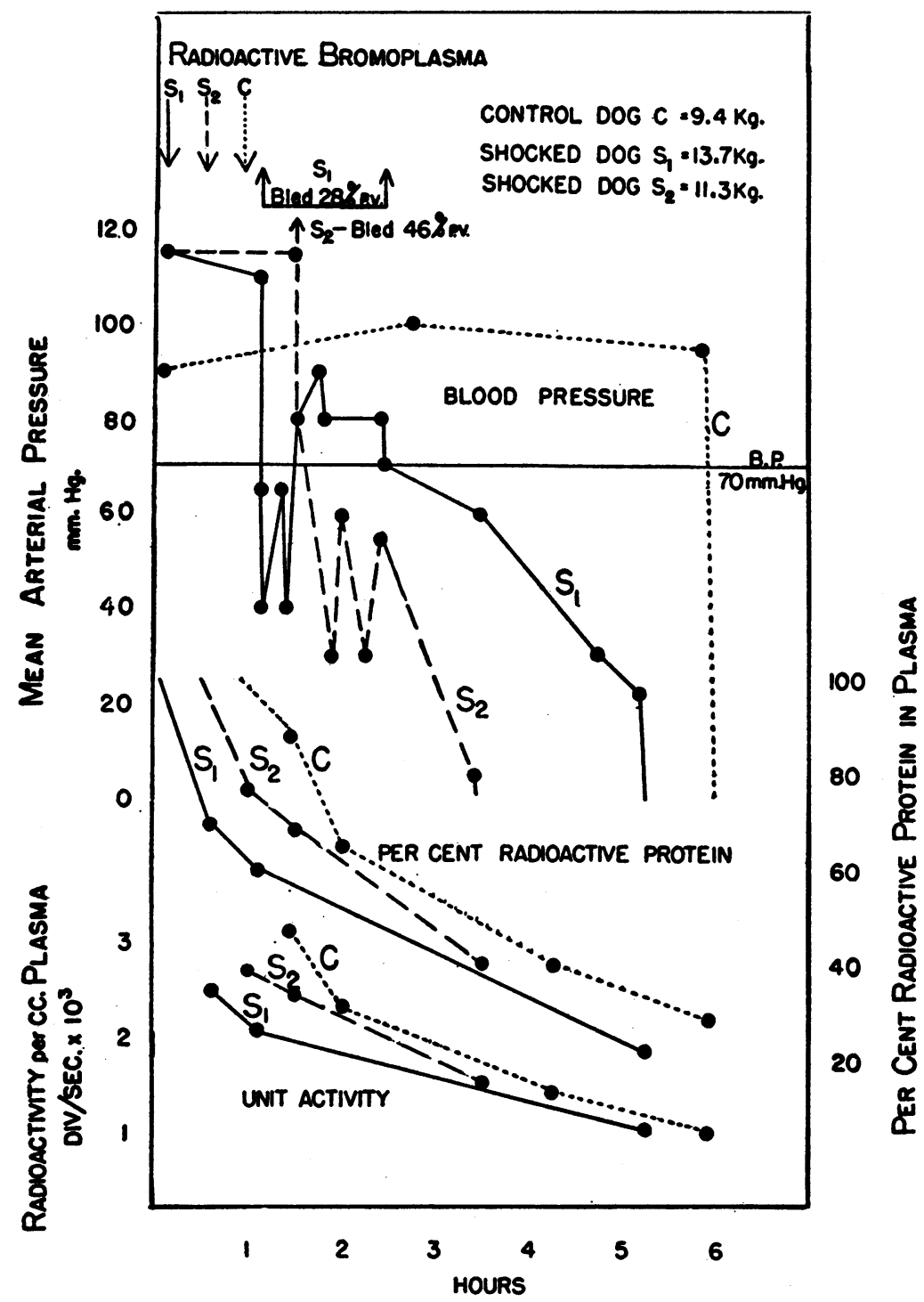

Fig. 2. EXPERIMENT 13

Since the slopes of the radioactivity curves in all three dogs show an approximately parallel course, it follows that the shocked dogs did not lose radioactive protein from the plasma at a greater rate than the control dog.

See Table II for tissue analyses. No evidence of plasma protein loss (within the limits of error) was noted in the shocked $\operatorname{dog} S_{1}$, as compared to the control dog. 


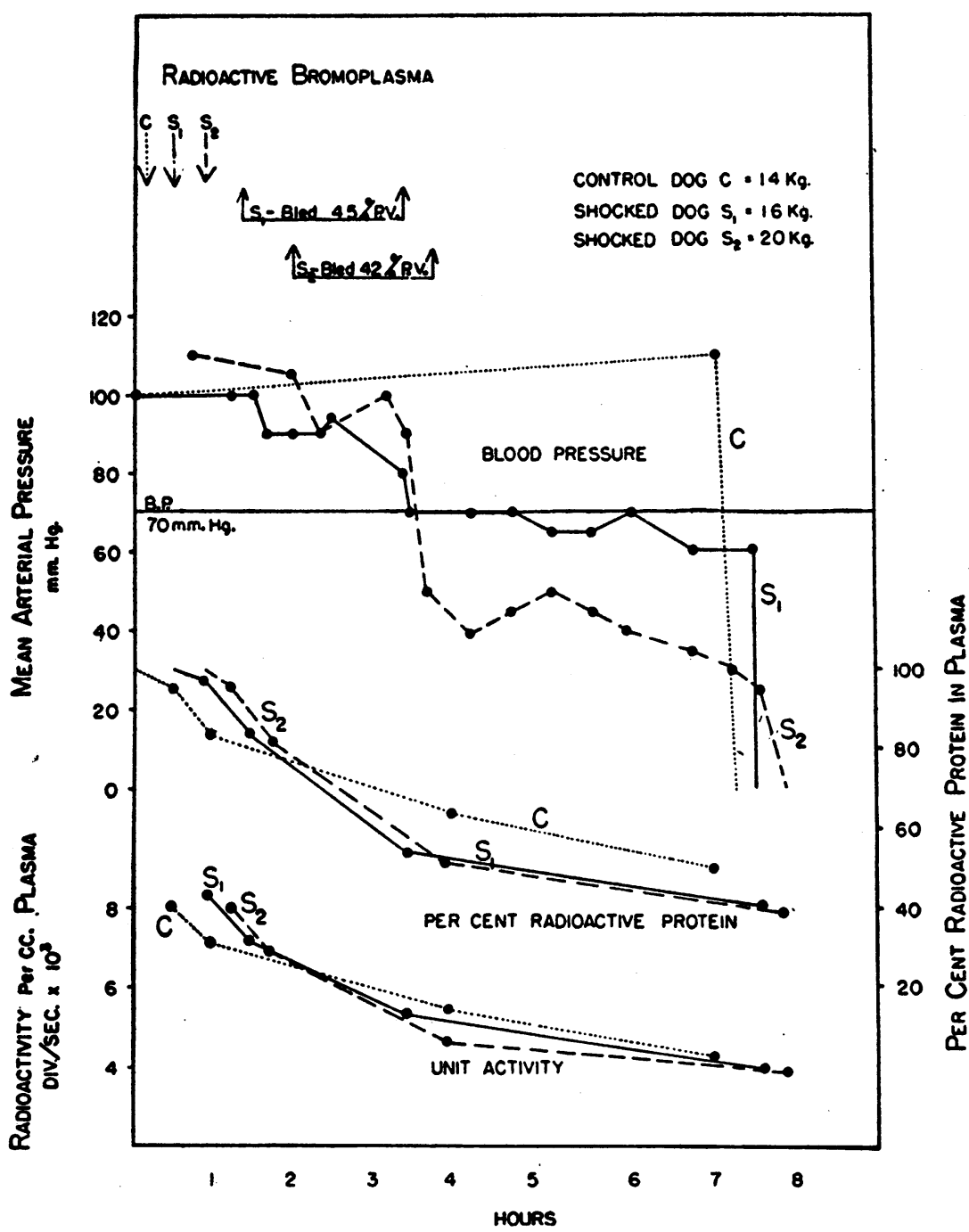

Fig. 3. ExprRiment 11

The increased slope of both radioactivity curves for dogs $S_{1}$ and $S_{2}$ as compared to that of $\operatorname{dog} C$, immediately after bleeding, is probably due to dilution by mobilized extravascular fluid. Their subsequent parallel. course indicates that the shocked dogs did not lose radioactive protein from the plasma at a greater rate than the control dog. There is no difference in the disappearance curves between the dog in deep shock $\left(S_{2}\right.$ probably irreversible) and the dog in less severe shock $\left(S_{1}\right.$ probably reversible).

See Table II for tissue analyses. Except for kidney $\left(S_{1}\right)$ and thoracic skin $\left(S_{1}\right.$ and $S_{2}$ ), no evidence of plasma protein loss in the shocked dogs as compared to the control dog was noted. The dog in deeper shock $\left(S_{2}\right)$ showed no significant increase in tissue radioactivity as compared to dog $S_{1}$. 


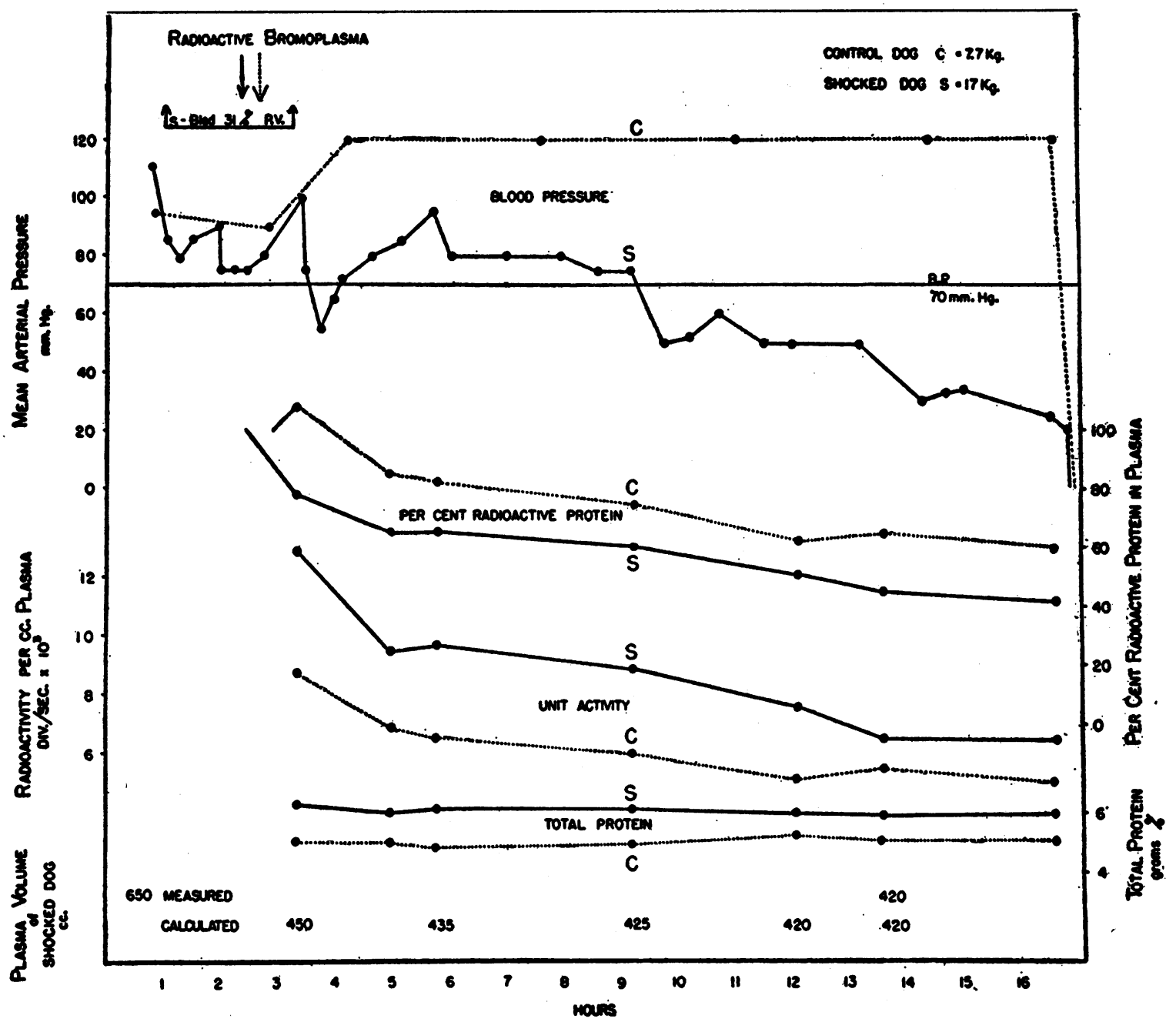

Fig. 4. EXPERIMENT 7

No evidence of significant hemoconcentration or hemodilution is obtained from the data. There is no greater rate of disappearance of radioactive protein from the circulating plasma in the shocked dog as compared to the control dog. No progressive loss of plasma was found with the dye method. The plasma volume 10 hours after hemorrhage is the same as that calculated on the basis of plasma removed in hemorrhage and sampling.

See Table II for tissue analyses. Plasma loss into ileum and liver was found. 


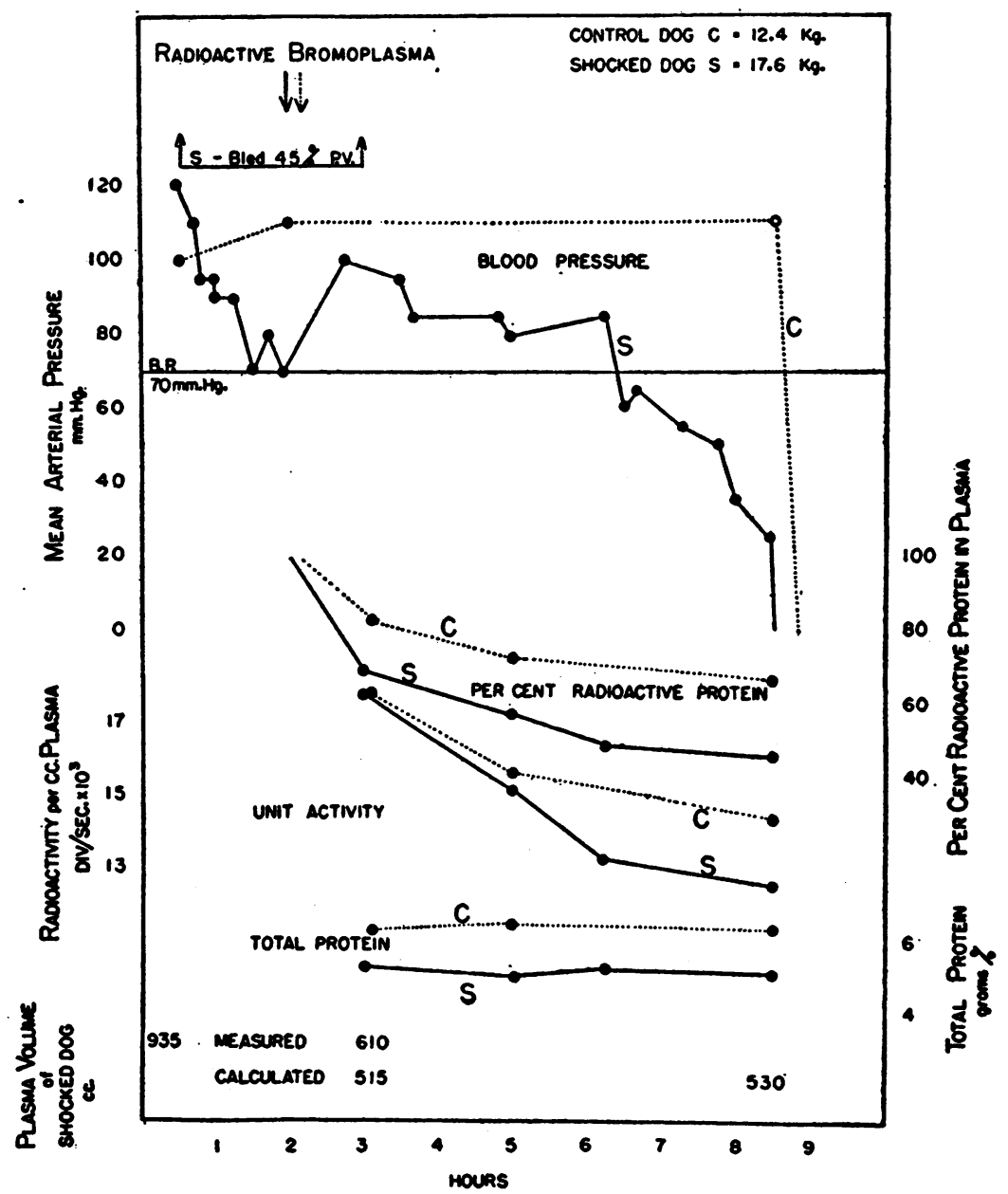

Fig. 5. EXPERIMENT 8

Evidence of slight hemodilution after hemorrhage is obtained from the total protein and radioactivity curves, as well as plasma volume measurements.

See Table II for tissue analyses. No plasma loss was found. 


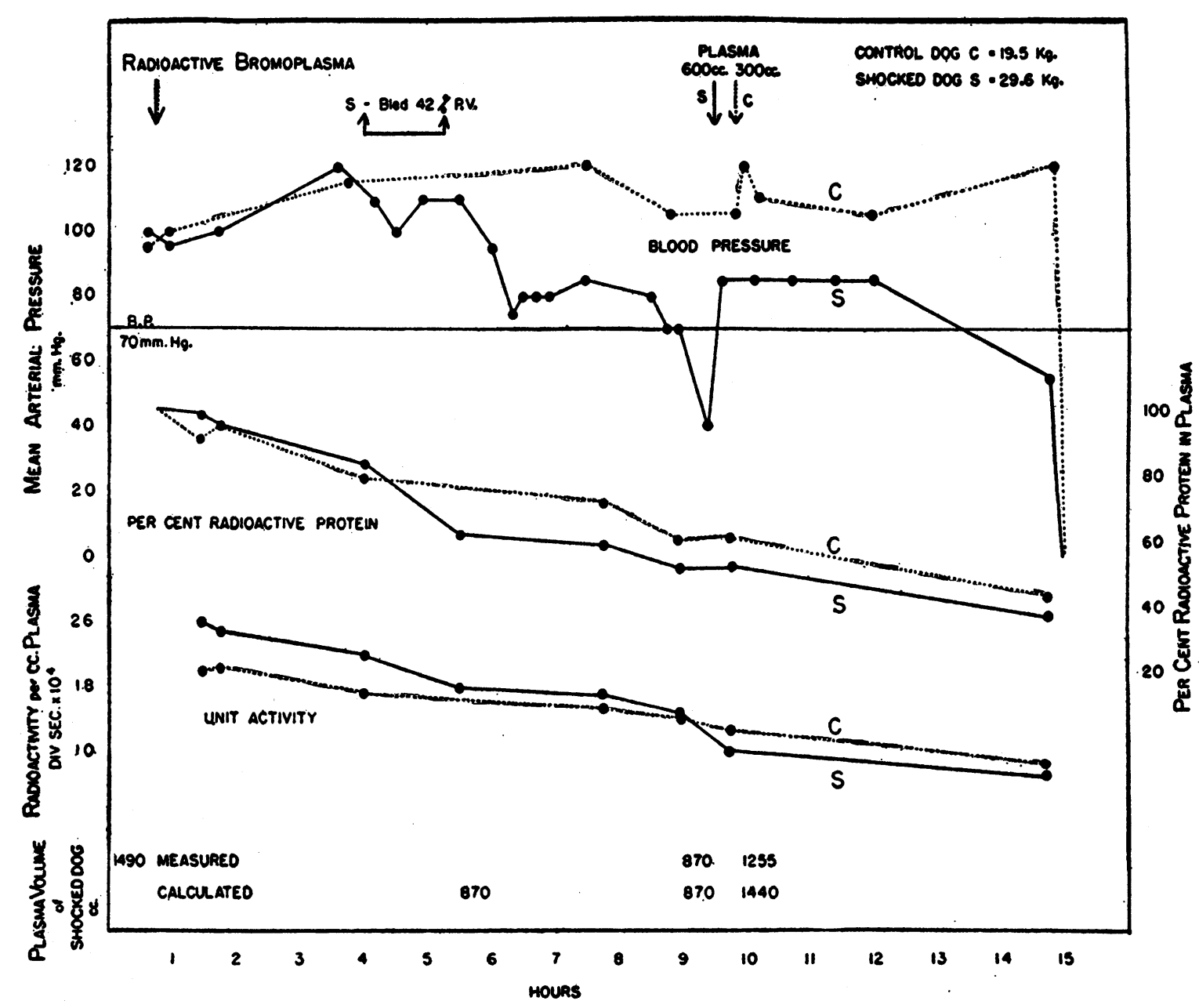

Fig. 6. ExpERnMENT 9

The parallel slopes of the radioactivity curves in shock and after a plasma infusion, indicate no greater loss of radioactive protein in the shocked dog than the control dog. Plasma volume measurements show no loss of plasma, except for that removed by hemorrhage, up to the time of the infusion. A deficiency of $185 \mathrm{cc}$. of plasma from the circulating plasma was found after the infusion. Since no change in concentration of radioactive protein was noted after the infusion had mixed, whole plasma must have been trapped out of active circulation or lost into tissue.

See Table II for tissue analyses. Loss of plasma into liver, skin, and leg muscle was found.

A similar experiment with 3 shocked dogs and 2 controls (Exp. 10 and 12, Table I) gave the same results. Radioactive protein disappeared from the circulating plasma at the same rate for both shocked and control dogs before and after plasma infusions. No tissue analyses were done in these dogs. 


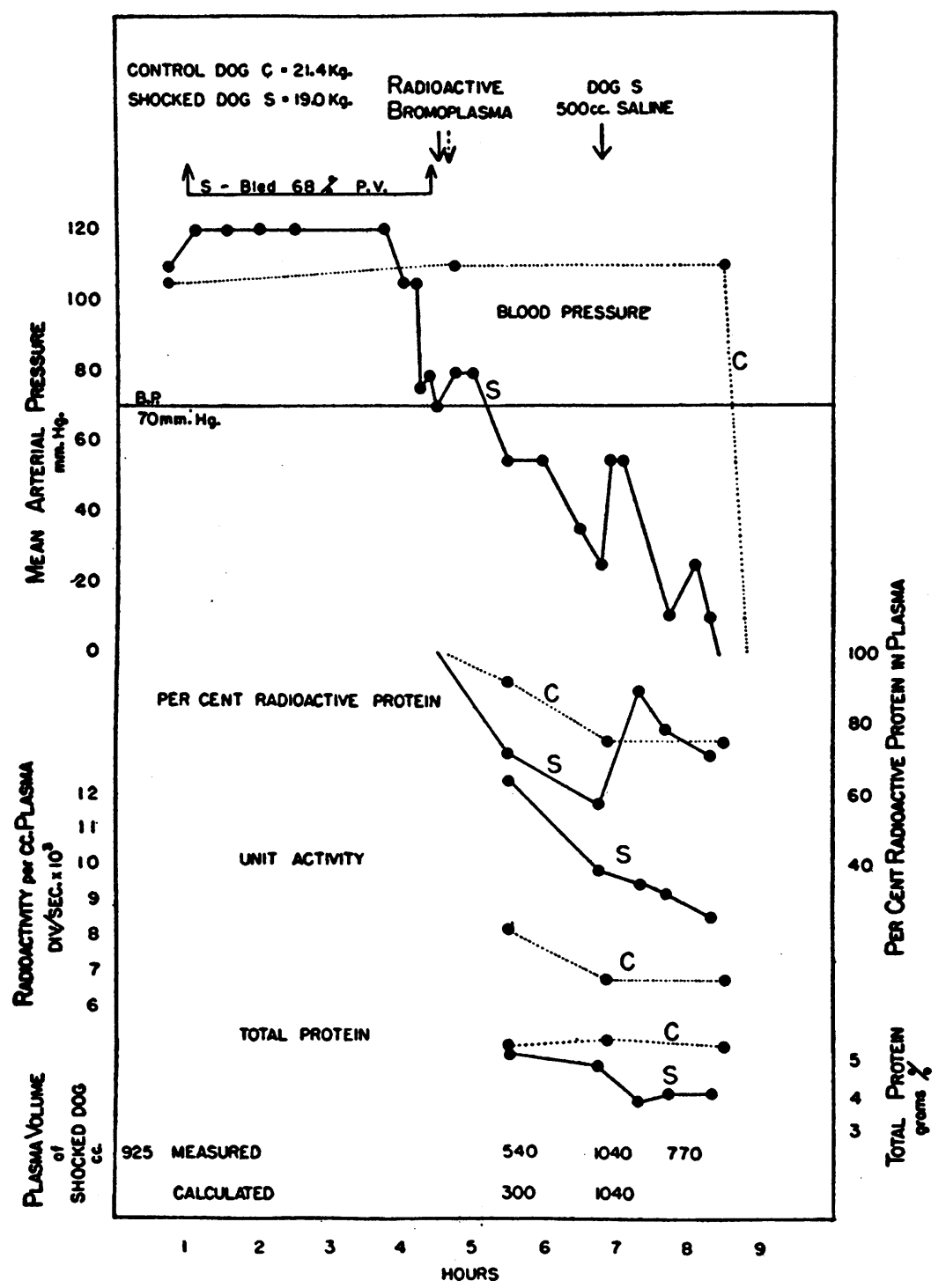

Fig. 7. Experiment 8A

Evidence of slight hemodilution is obtained from the plasma total protein and radioactivity curves, and plasma volume measurements early in shock. Marked dilution occurred after the infusion.

The percentage of radioactive protein circulating in the plasma increased after the saline infusion to a level higher than was noted immediately after the injection of the radioactive protein. This can only mean that due to poor mixing of the injected plasma during shock, some concentrated plasma was held stagnant in capillaries until it was washed into the circulation by the infusion.

See Table II for tissue analyses. If the plasma lost is assumed to have the activity noted at the end of the experiment, the difference in tissue activity (corrected) between control and shocked dog permits a calculation of the amount lost in liver to be $180 \mathrm{cc}$., in lung $40 \mathrm{cc}$., in skin $40 \mathrm{cc}$., and in leg muscle $27 \mathrm{cc}$. of plasma (total $287 \mathrm{cc}$.). Although the error introduced by this assumption gives higher values than probable, the data suggest loss of plasma protein into tissue following a saline infusion in late hemorrhagic shock. 


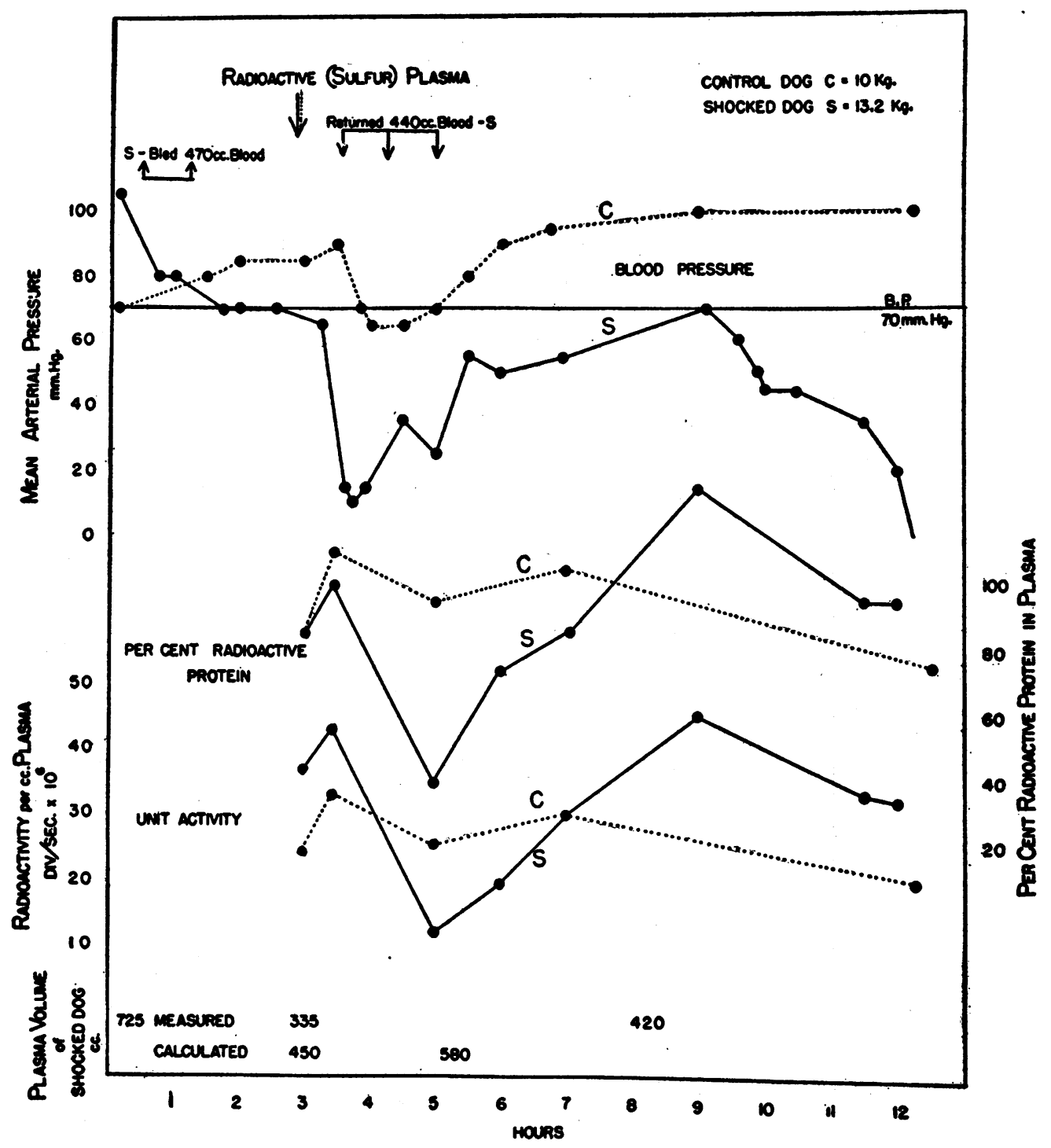

Fig. 8. Experiment S-1

Radioactive plasma containing radioactive sulfur was used. A plasma volume determination in the shocked dog at the beginning of the experiment, and just before the terminal decline in blood pressure, showed a deficiency of nearly $300 \mathrm{cc}$. of actively circulating plasma, even though nearly all the blood had been returned.

Inspection of the radioactivity curves shows a rapid loss of radioactive protein during the period of rapid collapse, and mobilization of radioactive protein into the active circulation after transfusion and rise in blood pressure had occurred. This finding is similar to that of experiment 8A, Fig. 7. Evidence of mobilization of radioactivity was not noted in experiments in which the radioactive protein was given before hemorrhage, when adequate mixing with the circulating plasma was allowed (Fig. 6). It is therefore possible that the observed phenomenon is due to inadequate mixing of radioactive plasma, rather than to loss through capillary leakage.

The plasma deficiency observed by the dye method is 37 per cent of the original volume. This is much higher than observed in any other experiment involving transfusion in the late shock phase (Table III). This suggests that the deficiency in part at least may have been due to poor mixing of dye. That inadequate mixing existed in this experiment was evident from the curve of radioactivity following injection of radioactive protein.

Another experiment (Experiment S-3, Table I) was done in which radioactive plasma containing 
their weight, the existing differences in unit and total radioactivity of plasma, the volumes of hemorrhage, and of transfusion.

This correction ${ }^{2}$ assumes that the plasma volume is variable (hemorrhage or transfusion), and that the capillary bed is about constant in area for any one animal.

Equating the activity lost from the blood to the activity gained by the tisues we have:

(1) $T A=V P_{0}\left(U A_{0}-U A_{h}\right)+\left(V P_{0}-V_{h}\right)\left(U A_{h}-U A_{t r}\right)$ where $+\left(V P_{0}-V_{h}+V_{t r}\right)\left(U A_{x}-U A_{t}\right)$

$T A=$ Total radioactivity in the extravascular component of tissue

$V P_{0}=$ Plasma volume at zero time

$V_{h}=$ Plasma volume of withdrawn blood

$V_{t r}=$ Volume of transfusion (plasma or saline)

$U A_{0}=$ Unit activity of plasma at zero time

$U A_{h}=$ Unit activity of plasma just before hemorrhage

$U A_{t r}=$ Unit activity of plasma just before transfusion

$U A_{x}=$ Unit activity of plasma just after transfusion

$U A_{t}=$ Unit activity of plasma at time of death

Following a transfusion of non-radioactive plasma or saline, the total radioactivity circulating before transfusion may be equated to the total radioactivity circulating after transfusion as follows:

(2)

$$
\left(V P_{0}-V_{h}\right) U A_{t r}=\left(V P_{0}-V_{h}+V_{t r}\right) U A_{z}
$$

We have by substitution in (1),

(3) $T A=V P_{0}\left(U A_{0}-U A_{t}\right)-V_{h}\left(U A_{h}-U A_{t}\right)-V_{t r}\left(U A_{t}\right)$

or

(4) $T A=V P_{0} U A_{0}-V_{h} U A_{h}-\left(V P_{0}-V_{h}+V_{t r}\right) U A_{t}$

where

$V P_{0} U A_{0}=$ Total radioactivity injected (This value does not depend on a plasma volume determination)

$V_{h} U A_{h}=$ Total radioactivity removed by hemorrhage

$\left(V P_{0}-V_{h}+V_{t r}\right) U A_{t}=$ Total radioactivity ${ }^{3}$ left in the circulation at the time of death.

Where no transfusion is given $V_{t r}=0$. If $F$ is the fraction of extravascular radioactivity per gram of dog (assuming the radioactivity lost from the blood to be evenly distributed throughout the animal) found in 1 gram of a

2 We are indebted to Professor Robley Evans, Massachusets Itnstitute of Technology, for deriving the following equations. particular tissue, then

$$
F=\frac{A}{\frac{T A}{W}}
$$

where

$A=$ The observed radioactivity of 1 gram of tissue

$T A=$ Total radioactivity in the extravascular component of tissue (see equation (4))

$W=$ Body Weight.

It follows that

$$
\frac{F_{\mathrm{s}}}{F_{\mathrm{c}}}=\frac{A_{\mathrm{s}}}{A_{\mathrm{o}}} \times \frac{W_{\mathrm{e}}}{W_{\mathrm{c}}} \times \frac{T A_{\mathrm{c}}}{T A_{\mathrm{s}}}
$$

when the subscript $c$ represents the control dog and $s$ represents the shocked dog. Now $\frac{A_{s}}{A_{0}}$ is the "actual" ratio given in Table II. The "corrected" ratio $\frac{F_{a}}{F_{0}}$ is obtained by multiplying the "actual" ratio by the "corrected factor," $\frac{W_{s}}{W_{0}} \times \frac{T A_{\mathrm{o}}}{T A_{\mathrm{s}}}$ (Table II).

\section{RESULTS}

The data of the individual experiments are shown in Figures 2 to 8 , with accompanying legends. Table I summarizes protocol data which may be used as a reference for the interpretation of Table II, which gives the data in regard to plasma protein loss into various tissues.

\section{COMMENTS}

From the figures of the foregoing experiments, it may be stated that the radioactivity curves of the circulating plasma in normal and shocked dogs, which have not received infusions, are substantially the same. The disappearance of radioprotein from the circulation, as judged by the

3 Whenever available, a measured plasma volume was used instead of the theoretical volume $\left(V P_{0}-V_{h}+V_{t r}\right)$. When actual plasma volumes were not available, the estimated volume was used. This estimated volume we regard as reliable because the average difference between actual and expected plasma volumes in the early phase of shock is 9.3 per cent while in the late phase this difference is even less, except when infusions are given (See Table III).

radioactive sulfur was injected before hemorrhage. Both control and shocked dogs suffered a nitritoid reaction with a drop in blood pressure to $70 \mathrm{~mm}$. Hg. During the succeeding 6 hours, both blood pressures returned to normal. The shocked dog was then bled and shock ensued for 3 hours with a gradual decline of blood pressure to $45 \mathrm{~mm}$. $\mathrm{Hg}$. Blood withdrawal for plasma volume determination killed the shocked dog.

Six hours after the injection of radioactive plasma, the per cent of radioactive protein circulating in the plasma and the unit activity of plasma was about the same in both dogs. The slopes of the curves remained parallel during the onset of shock in the shocked dog. These observations are similar to those noted with radioactive bromoprotein (Figs. 2 and 3 ). 
TABLE I

Summary of protocol:data

\begin{tabular}{|c|c|c|c|c|c|c|c|c|c|c|}
\hline \multirow[b]{2}{*}{$\begin{array}{c}\text { Experi- } \\
\text { ment } \\
\text { number }\end{array}$} & \multirow[b]{2}{*}{$\begin{array}{l}\text { Figure } \\
\text { number }\end{array}$} & \multirow[b]{2}{*}{$\begin{array}{c}\text { Anesthesia } \\
\text { in addition } \\
\text { to morphine }\end{array}$} & \multicolumn{3}{|c|}{ Radioactive plasma } & \multirow{2}{*}{$\begin{array}{c}\text { Plasma } \\
\text { volume } \\
\text { removed } \\
\text { in hemor- } \\
\text { rhage }\end{array}$} & \multirow[b]{2}{*}{ Infusion } & \multirow{2}{*}{$\begin{array}{l}\text { Duration of } \\
\text { experiment } \\
\text { after injec- } \\
\text { tion of } \\
\text { radioplasma }\end{array}$} & \multirow[b]{2}{*}{$\begin{array}{l}\text { Dura- } \\
\text { tion of } \\
\text { shock }\end{array}$} & \multirow{2}{*}{$\begin{array}{c}\text { Plasma loss } \\
\text { from analysis } \\
\text { of tisue } \\
\text { (see Table II) }\end{array}$} \\
\hline & & & $\begin{array}{c}\text { Bromine in } \\
\text { bromoprotein }\end{array}$ & $\frac{\mathrm{W}_{e}}{\mathrm{~W}_{e}} \times \frac{\mathrm{I}_{\mathrm{e}^{*}}}{\mathrm{I}_{\mathrm{e}}}$ & $\begin{array}{l}\text { Injection } \\
\text { before or } \\
\text { after hem- } \\
\text { orrhage }\end{array}$ & & & & & \\
\hline $\begin{array}{l}13 S_{1} \\
13 S_{2} \\
11 S_{1}\end{array}$ & $\begin{array}{l}2 \\
2 \\
3\end{array}$ & $\begin{array}{l}\text { Novocaine } \\
\text { Novocaine } \\
\text { Novocaine }\end{array}$ & $\begin{array}{l}\text { per cent } \\
1.0 \\
1.0 \\
1.1\end{array}$ & $\begin{array}{l}1.0 \\
1.0 \\
1.0\end{array}$ & $\begin{array}{l}\text { Before } \\
\text { Before } \\
\text { Before }\end{array}$ & $\begin{array}{c}\text { per cent } \\
28 \\
46 \\
45\end{array}$ & $\begin{array}{l}\text { None } \\
\text { None } \\
\text { None }\end{array}$ & $\begin{array}{c}\text { hours } \\
3 \\
5 \\
7.5\end{array}$ & $\begin{array}{c}\text { hours } \\
2 \\
4 \\
4\end{array}$ & $\begin{array}{l}\text { No loss } \\
\text { Kidney, tho- }\end{array}$ \\
\hline $\begin{array}{c}11 \mathrm{~S}_{2} \\
7 \\
8 \mathrm{~B} \\
9\end{array}$ & $\begin{array}{l}3 \\
4 \\
5 \\
6\end{array}$ & $\begin{array}{l}\text { Novocaine } \\
\text { Sod. barb. } \\
\text { Sod. barb. } \\
\text { Sod. barb. }\end{array}$ & $\begin{array}{l}1.1 \\
0.1 \\
1.2 \\
0.1\end{array}$ & $\begin{array}{l}1.0 \\
0.91 \\
0.64 \\
0.87\end{array}$ & $\begin{array}{l}\text { Before } \\
\text { After } \\
\text { After } \\
\text { Before }\end{array}$ & $\begin{array}{l}42 \\
31 \\
45 \\
42\end{array}$ & $\begin{array}{l}\text { None } \\
\text { None } \\
\text { None } \\
\text { Plasma }\end{array}$ & $\begin{array}{c}7.5 \\
14 \\
6.5 \\
14\end{array}$ & $\begin{array}{c}4.5 \\
11 \\
7 \\
9\end{array}$ & $\begin{array}{l}\text { Kidney } \\
\text { Liver, ileum } \\
\text { No loss } \\
\text { Liver, skin, leg }\end{array}$ \\
\hline $\begin{array}{l}10 \\
12 S_{1} \\
12 S_{2} \\
8 \mathrm{~A}\end{array}$ & 7 & $\begin{array}{l}\text { Sod. barb. } \\
\text { Sod. barb. } \\
\text { Sod. barb. } \\
\text { Sod. barb. }\end{array}$ & $\begin{array}{l}5.4 \\
0.3 \\
0.3 \\
1.2\end{array}$ & $\begin{array}{l}1.0 \\
1.0 \\
1.0 \\
0.84\end{array}$ & $\begin{array}{l}\text { Before } \\
\text { Before } \\
\text { Before } \\
\text { After }\end{array}$ & $\begin{array}{l}15 \\
30 \\
43 \\
68\end{array}$ & $\begin{array}{l}\text { Plasma } \\
\text { Plasma } \\
\text { Plasma } \\
\text { Saline }\end{array}$ & $\begin{array}{r}8 \\
9 \\
10 \\
4\end{array}$ & $\begin{array}{l}4.5 \\
6 \\
7 \\
4\end{array}$ & $\begin{array}{l}\text { Liver, lung, } \\
\text { skin, leg } \\
\text { muscle }\end{array}$ \\
\hline$S-1$ & 8 & Sod. barb. & Radiosulph- & 0.76 & After & 39 & Blood & 9 & 10 & \\
\hline$S-3$ & & Sod. barb. & $\begin{array}{l}\text { Radiosulph- } \\
\text { protein }\end{array}$ & 0.94 & Before & 25 & Plasma & 9.5 & 3 & \\
\hline
\end{tabular}

* This factor is the ratio of the proportion of plasma given to body weight of shocked dog to control dog, when $\mathrm{W}=$ wt. of dog, $\mathrm{I}=$ volume of radioactive plasma injected, $\mathrm{c}=$ control, $\operatorname{dog}$ and $\mathrm{s}=$ shocked dog.

curves of unit or residual radioactivity, occurs at approximately the same rate in the shocked and normal dog receiving the same specimens of radioactive bromoplasma. The unit radioactivity curves provide evidence as to whether or not a selective loss of protein or a shift in total water occurs in shock. The residual radioactive protein curves provide evidence as to whether or not whole plasma is lost in shock. But the validity of this latter curve depends on the validity of plasma volume determinations. Since there is doubt as to the reliability of plasma volume determinations under all circumstances, the conclusion from the slopes of the residual radioactive protein curves as to plasma loss into tissues is hazardous without a simultaneous comparison of the tissue content of radioactive protein in the normal and shocked dog. Such tissue analyses are useful not only for detecting plasma loss, but also for locating the area into which loss takes place.

\section{Results of tissue analyses}

Table II includes all measurements of radiobromoprotein in tissues, expressed as the ratio of the radioactivity of one gram of a given tissue in the shocked dog to that of the control dog. The actual ratio is corrected, as previously pointed out, to account for differences between these dogs in weight, in unit radioactivity of plasma, and in the total volume of circulating radioactive protein.

A corrected ratio of 100 per cent indicates equal escape of radiobromoprotein in the shocked and control dog. Assuming the error of the analytical technique to be some 5 to 25 per cent, ${ }^{4}$ a corrected ratio of over 125 may be taken to indicate an excess of radiobromoprotein in the tissue of the shocked dog over that in the same tissue in the normal dog. Corrections for blood content of tissues were also made, in some experiments, in kidney, lung, and liver, in which the radioactivity due to blood varied from $2 \frac{1}{2}$ to $71 / 2$ per cent, 2 to 30 per cent, and 1 to 9 per cent, respectively.

A corrected ratio in excess of 125 may be taken to indicate loss from the circulation of whole plasma because the loss of circulating protein

4 The range of error in the oxidation technique and measurement of radioactivity with the electroscope is 5 to 25 per cent, as shown in Table II and III of a foregoing publication in this series (5). 


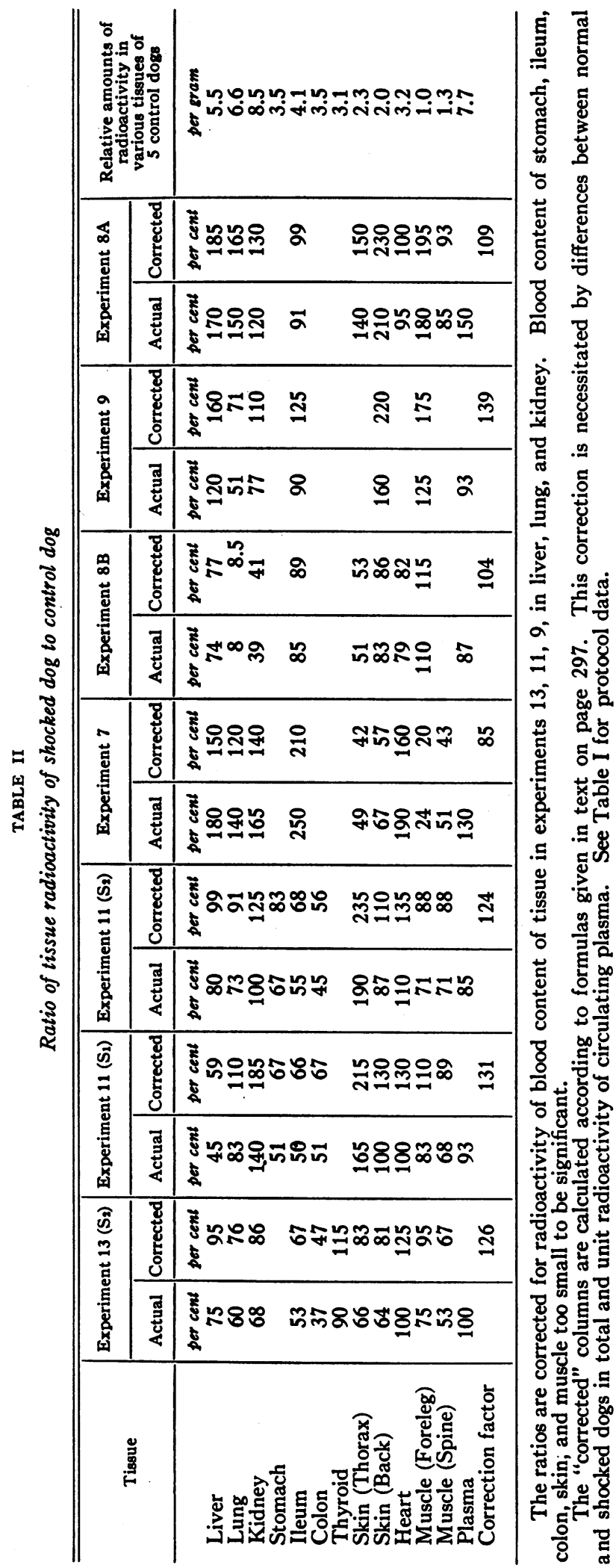


without concomitant loss of the equivalent nonprotein fraction would result in a fall in plasma protein concentration, while a loss of the nonprotein fraction without loss of the equivalent protein fraction would cause a rise in the plasma protein concentration. Since the plasma protein concentration does not vary after the initial hemorrhage, except when infusions are given in late shock, protein loss is in proportion to whole plasma loss. This loss cannot be quantitated accurately because the unit activity of the lost plasma is not precisely known.

The ratios found in Experiments 13, $11\left(\mathrm{~S}_{1}\right)$, $11\left(\mathrm{~S}_{2}\right), 7$, and $8 \mathrm{~B}$ show no material difference between shocked and normal dogs in the amount of radioactive protein which has entered tissues from the circulation.

Where the ratios in certain exceptional instances are high, special analysis of their quantitative significance is necessary in organs whose weight is a substantial fraction of the total body weight. These include skeletal muscle, skin, liver, and gastro-intestinal tract. In skeletal muscle, no high ratio was found. In skin, a high ratio was found in 2 of 10 , in liver in 1 of 5 , and in gastro-intestinal tissue in 1 of 9 determinations.

In Experiments 13 and 8B, no loss of significance was observed in any tissue. In Experiment $11\left(\mathrm{~S}_{1}\right)$, skin of thorax showed a loss. If the skin of thorax is assumed to be some 10 per cent of the whole skin, the amount lost into it was calculated $^{5}$ as 45 cc. In this experiment, total loss is also significant. In Experiment $11\left(\mathrm{~S}_{2}\right)$, the same conclusion results, since the only loss was $60 \mathrm{cc}$. into the skin of the thorax. In Experiment 7, liver showed a loss of $35 \mathrm{cc}$. It is in this experiment that bowel showed a loss but we do not regard it as significant because it is the only instance in all our experiments, in which loss into bowel was observed.

Although the extent of plasma loss in these

\footnotetext{
5 This calculation assumes that the plasma lost into the organ has the unit activity of the circulating plasma measured at the end of the experiment. The difference between the control and shocked dogs in corrected tissue activity, multiplied by the organ weight, and divided by this unit activity of plasma, provides the figure used. This calculation is of course only an approximate figure and weights the error in the direction of greatest loss.
}

experiments cannot be accurately assessed, the data on the whole indicate that such loss is small, that it involves only one or two tissues, which vary from one experiment to another, and that it is probably not quantitatively significant except when infusions are given in the late shock phase. Indeed the frequency with which one observes (in Table II) a substantially smaller content of radioactive plasma in the tissue of the shocked as compared to the control dog suggests that the reverse may be true, i.e. that less plasma moves out of the circulation in the shocked dog, presumably because of the contracted volume and decreased velocity of flow in the general capillary bed (10).

That plasma loss of perhaps significant proportions may occur when infusions are given in irreversible shock is evident from the data of Experiments 9 and 8A. A plasma infusion in the irreversible phase was given in Experiment 9 and a saline infusion in Experiment 8A. The skin and liver showed a high ratio in the shocked dogs of these experiments. Two of the three muscle determinations made showed high ratios. The only instance in which a high value for lung was observed was in Experiment 8A. The quantitative significance of the total loss in Experiment $8 \mathrm{~A}$ (saline infusion) is probably substantial (see Legend to Figure 7). It is pertinent to refer here to the observation of Werle, Cosby, and Wiggers (11) that the exposed mucous membrane of the intestine in hemorrhagic shock was pale and shrunken, and only became engorged or hemorrhagic after fluids were given intravenously in the late shock phase.

The continued fall in unit concentration of radioactivity without a simultaneous escape of whole plasma, observed in all the uninfused control and shocked dogs studied, signifies dilution or escape of radioactive protein from the circulation. Continuous dilution does not occur in the normal dog and while there is evidence of fluid mobilization early in shock, this is certainly not true later on. Since the unit activity fell at the same rate in the normal and the shocked dogs, the equal loss of radioactive protein in both therefore signifies that the normal mechanism for the escape of such protein from the circulation was operating in both.

Other evidence that whole plasma does not 
TABLE III

Plasma volume in hemorrhagic shock

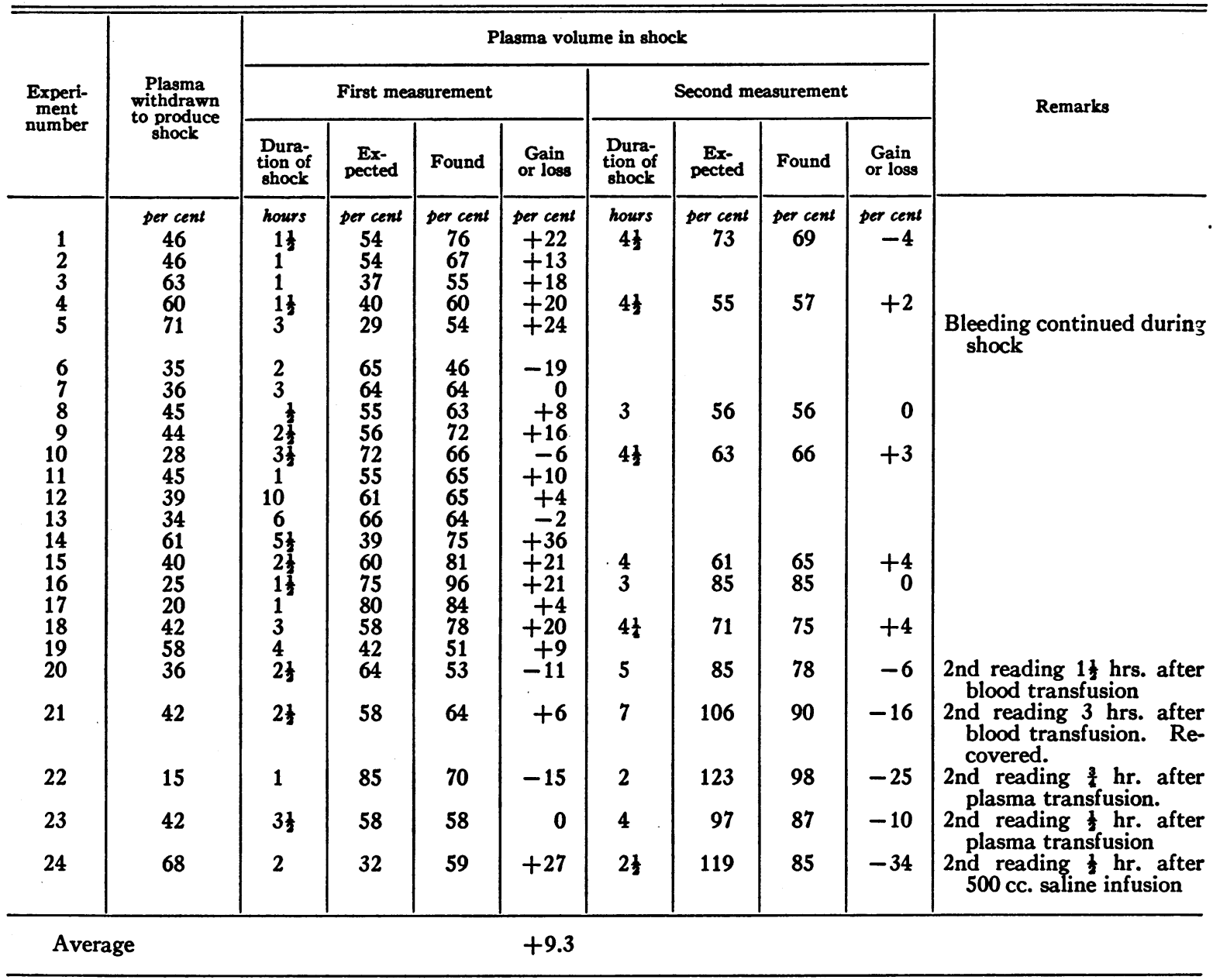

All dogs died except as noted.

escape from the circulation in uninfused dogs in hemorrhagic shock is provided by the data in Table III, ${ }^{\circ}$ showing plasma volumes in a group of shocked dogs. These volumes were determined by the method of Gibson and Evelyn (7).? All stages of shock were involved and it is evident

6 This table, prepared by Dr. Howard Frank, includes data from a variety of experiments on shock, some of which have already been reported (Frank, H. A. and Fine, J., J. Clin. Invest., 1943, 22, 305, and Fine J., Fischmann, J., and Frank, H. A., Surgery, 1942, 12, 1.

7 The error of the method was doubled in certain instances in which the galvanometer setting was 50 instead of 100. Such errors however would not affect the interpretation of the figures as presented.
(1) that there is no correlation between the volumes gained or lost and the duration or severity of shock; (2) only 4 of 24 dogs showed a loss, while 20 showed a gain-the average gain, 9.3 per cent. When plasma volume was measured again after a subsequent interval of shock (12 experiments), there was no significant gain or loss in this interval in 7. An average loss of 19 per cent in the remaining 5 occurred, but all of these were instances in which a preceding saline, plasma, or blood infusion had been given in the late shock phase, and the expected volume included the volume of the infusion. Whether the discrepancy between the expected and in- 
creased volumes in these 5 instances represents a true loss into tissues, or inadequate mixing of dye with capillary blood, is not clear and remains to be determined.

Our conclusion is that plasma volume does not fall beyond that accounted for by the amount withdrawn. This conclusion however rests upon the validity of the dye method. Since the rate of escape of dye from the blood stream during the period of measurement is corrected for by extrapolation of the disappearance curve, the two factors that may upset a true dilution figure are incomplete mixing with the peripheral stream or a measurement of dilution before complete mixing occurs. Although peripheral stagnation exists in shock, this is not equivalent to complete stasis. Complete mixing is therefore merely a function of time. The period of time for complete mixing is not known. In our experiments, three readings were made in a period of 20 to 35 minutes after dye injection. Assuming incomplete mixing, the result would be a false one, but in the direction of loss rather than gain because of the smaller volume involved if the mixing is incomplete. False values, which would be most likely in late shock, would therefore overestimate loss. Since our figures are already in favor of no loss, error in the method would only lend further strength to our conclusion. The results with respect to plasma loss obtained by the dye volume method therefore agree with those obtained by the radioactive protein technique.

\section{DISCUSSION}

Since the evidence is against a significant loss of plasma, from plasma volume studies and from the experiments with radioactive protein in which no infusions were given, the conclusion follows that death in hemorrhagic shock is not due to a progressive decline in plasma volume. It appears therefore that the changes induced by the initial decline in plasma volume are the cause of death and that the progressive disorder in hemodynamic equilibrium does not arise from an increasing imbalance in the fluid exchange between blood and tissues. The continuing local loss in burns or in areas of trauma do indeed constitute a progressive decline in plasma vol- ume, but the difference between these states and hemorrhagic shock where hemorrhage has stopped may be merely a quantitative rather than a qualitative one. Toxic factors may also act deleteriously in burns or trauma, but as the mechanisms causing death in hemorrhagic shock seem not to involve capillary leakage, death from burns or trauma need not do so either. For, once the latter have produced a sufficient initial decline in plasma volume, the fatal mechanism is in operation without postulating still further decline as a necessary part of the fatal mechanism. This is an important consideration because even if one could correct a generalized increase in capillary permeability, death from burns or trauma would still result from the initial decline alone, if not corrected early enough. Therein lies the crux of the matter. For while the associated phenomena in different types of shock modify the pattern of events impressively, beneath them a mechanism exists, which in itself has fatal potentialities and which can produce all the basic phenomena common to all types of shock-namely, peripheral stagnation, lowered systolic and diastolic pressure, lowered venous oxygen, lowered venous pressure, decreased venous return, decreased cardiac output, increase in acid metabolites, and death.

\section{SUMMARY AND CONCLUSIONS}

A method is described for preparing radioactive bromoprotein which when infused into normal dogs behaves not unlike undenatured plasma protein (e.g. protein containing radioactive sulfur).

A technique of preparing tissue and plasma for radioactivity determinations is also described.

Radioactive proteins were given intravenously to normal dogs and dogs in hemorrhagic shock, both with and without anesthesia. Control dogs received the same radioactive protein given to the shocked dog in any single experiment. Disappearance curves of this radioactive protein from the circulation were obtained and plotted in terms of unit radioactivity and residual circulating radioactive protein. From these curves, the evidence was derived that the radioactive proteins disappear from the circulation at the same rate in normal and shocked dogs and that the 
dog in shock from hemorrhage does not lose plasma into tissues. Tissue analyses of radioactive protein in these dogs gave the same result.

However, when the shocked dogs received intravenous infusions in the late or irreversible phase of shock, the radioactivity content of some tissues showed that plasma protein was lost into some tissues in possibly significant quantity. Similar evidence was obtained from plasma volume studies which showed that the deficiency in circulating plasma volume, created by the hemorrhage performed to induce shock, did not increase as shock progressed. If, however, infusions were given in the late shock phase, the expected volume was greater than the volume found. The data at hand were insufficient to determine whether the diminished volumes when found were due to actual leakage or inadequate mixing.

While the integrity of the capillaries may be impaired in the late shock phase, there is no evi- dence of a significant loss of plasma into tissues in untreated fatal shock following hemorrhage. Hence, an increase in capillary permeability is not a factor in the fatal issue. The phenomena which are set in motion by the initial critical loss in circulating plasma volume and which lead to death do not require that a progressive decline in plasma volume take place. Plasma loss into tissues therefore is not a crucial factor in hemorrhagic shock.

Acknowledgment is due Miss Martha Goldberg for technical assistance.

The work described in this paper was done under a contract, recommended by the Committee on Medical
Research, between the Office of Scientific Research and Development and Harvard University.

\section{BIBLIOGRAPHY}

1. Seligman, A. M., Rutenburg, A. M., and Banks, H., The preparation of cystine, methionine, and hemocystine containing radioactive sulfur. J. Clin. Invest., 1943, 22, 275.

2. Seligman, A. M., and Fine, J., The production of radioactive plasma protein from amino acids containing radioactive sulfur. J. Clin. Invest., 1943, 22, 265.

3. Cohn, E. J., Hendry, J. L., and Prentiss, A. M., Studies in physical chemistry of proteins: Molecular weights of proteins: Minimal molecular weights of certein proteins. J. Biol. Chem., 1925, 63, 721.

4. Wormall, A., Immunological specificity of chemically altered proteins: Halogenated and nitrated proteins. J. Exper. Med., 1930, 51, 295.

5. Seligman, A. M., A modified electroscope especially suited for measuring substances with low energy radiation. J. Clin. Invest., 1943, 22, 281.

6. Wiggers, C. J., Present status of shock problem. Physiol. Rev., 1942, 22, 74.

7. Gibson, J. G., and Evelyn, K. A., Clinical studies of blood volume: Adaptation of method to photoelectric colorimeter. J. Clin. Invest., 1938, 17, 153.

8. Kagan, B. M., Simple method for estimation of total protein content of plasma and serum: Estimation of total protein content of human plasma and serum by use of falling drop method. J. Clin. Invest., 1938, 17, 373.

9. Bing, F. C., Purification of benzidine, and an improved reagent for estimating hemoglobin in blood. J. Biol. Chem., 1932, 95, 387.

10. Frank, H. A., and Fine, J., A study of the effect of oxygen on hemorrhagic shock. J. Clin. Invest., 1943, 22, 305.

11. Werle, J. M., Cosby, R. S., and Wiggers, C. J., Observations on hemorrhagic hypotension and hemorrhagic shock. Am. J. Physiol., 1942, 136, 401. 